DOI: https://doi.org/10.24127/ajpm.v8i1.1826

\title{
PENGEMBANGAN MODUL PEMBELAJARAN MATEMATIKA PADA MATERI STATISTIKA TERINTEGRASI NILAI-NILAI KEISLAMAN
}

\author{
Tia Ekawati ${ }^{1}$, Bambang Sri Anggoro ${ }^{2}$ Komarudin $^{3}$ \\ 1,2,3 Pendidikan Matematika, UIN Raden Intan Lampung \\ E-mail: $\quad$ tiaekawati2019@gmail.com ${ }^{1)}$ \\ bambangsrianggoro@gmail.com ${ }^{2)}$ \\ komarudin@radenintan.ac.id ${ }^{3)}$
}

Received 15 Februari 2019; Received in revised form 4 April 2019; Accepted 10 May 2019

\begin{abstract}
This study aims to study the feasibility and convenience as well as the use of mathematical modules in statistical material integrated with developed Islamic values. The research and development procedures used were the development models of Borg and Gall. Expert validation is carried out by: (i) material experts; (ii) media experts; and (iii) religious experts. Small group trials were conducted on 6th grade students of MTs Al Huda Bandung Baru as many as 6 students and a field trial of 30 students. The results of this study consisted of a mathematics learning module on integrated statistical material Islamic values which included semester VIII statistical material 2. The feasibility of a mathematics learning module that was integrated with Islamic values based on validators, prospective research, and module attractiveness. interesting module that calculates $N$-Gain calculations included in the high category.
\end{abstract}

Keywords: Integration of Islamic values; Module.

\section{PENDAHULUAN}

Pendidikan mengandung makna suatu kegiatan proses pembelajaran yang terencana yang dapat mengaktifkan peserta didik untuk mengembangkan potensi dirinya sehingga mampu menghadapi setiap perubahan yang terjadi akibat adanya kemajuan ilmu pengetahuan dan teknologi (Lestari dan Handayani, 2018; Sania dan Farlina, 2017). Pembelajaran matematika merupakan usaha untuk membantu peserta didik mengkonstruksi pengetahuan melalui proses (Masykur, Novrizal dan Syazali, 2017; Afifah, 2012).

Terdapat banyak ayat Al-Qur'an yang memotivasi seseorang untuk menuntut ilmu pengetahuan. Salah satunya Al-Qur'an surat Al-Mujaadilah ayat 11 :

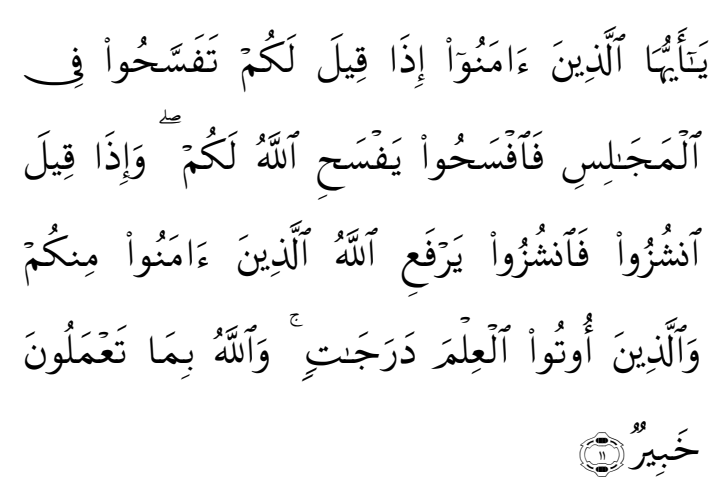

Artinya: "Allah akan meninggikan orangorang yang beriman diantara kamu dan orang-orang yang diberi ilmu pengetahuan beberapa derajat. Dan Allah maha mengetahui apa yang kamu kerjakan".

Sebagaimana yang diketahui bahwa menurut Al-Qur'an, manusia berpotensi untuk menguasai ilmu pengetahuan. Pembelajaran matematika dapat membentuk logika berfikir bukan hanya sekedar pandai berhitung. 
Matematika pada dasarnya mengajarkan logika berfikir, berdasarkan akal dan nalar. Namun, harus diingat pada dasarnya sifat dari matematika itu abstrak dan tidak nyata karena terdiri dari simbol-simbol. Dengan demikian, matematika sebagai ilmu pengetahuan bisa digunakan sebagai pendekatan dalam menjelaskan beberapa penjelasan dalam ajaran islam (Nasruddin, 2014).

Maka dari itu perlu pendidikan yang mengajarkan nilai-nilai dan dapat membentuk kepribadian berkarakter, berakhlak mulia dan beradab yaitu pendidikan islam. Nilai-nilai islam dapat diintegrasikan dalam proses pembelajaran khususnya dalam pembelajaran matematika. Oleh sebab itu diperlukan suatu pembelajaran matematika yang mengintegrasikan nilai islam pada topik matematika sekolah. Tetapi ketersediaan modul sebagai bahan ajar mungkin sudah banyak dijumpai di sekolah-sekolah, namun ketersediaan modul yang yang memiliki nilai-nilai keislaman dengan model pembelajaran kontekstual masih jarang digunakan dalam menyampaikan pembelajaran (Diana, Netriwati dan Suri, 2018; Supriadi, 2015).

Berdasarkan pra-penelitian yang dilakukan pada peserta didik kelas VIII di MTs Al Huda Bandung Baru, ditemukan beberapa masalah yang cukup serius diantaranya yaitu: bahwa peserta didik merasa kurang menyukai pelajaran matematika khususnya materi statistika karena dianggap sulit dipahami karena banyak rumus dan perhitungan yang membosankan serta bahan ajar yang digunakan hanya menggunakan buku cetak dan LKPD yang membuat peserta didik kurang berminat mempelajari matematika. Hal ini diperkuat dengan wawancara di MTs Al Huda Bandung pada hari senin, 9 April 2018 pukul 08.00 WIB dengan pendidik mata pelajaran matematika Ibu
Niswati Latifah, S.Pd. Beliau mengatakan bahwa bahan ajar yang tersedia sudah memadai namun masih ada yang kurang karena buku cetak yang digunakan terkadang kurang detail materinya, dengan bahan ajar yang beliau gunakan belum sepenuhnya berhasil karena masih banyak anak yang belum tuntas. Dalam pembelajaran matematika beliau belum pernah menggunakan modul pembelajaran matematika yang terintegrasi dengan nilai-nilai keislaman beliau hanya menggunakan buku cetak dan LKPD sebagai bahan ajar. Solusi untuk menyelesaikan masalah tersebut yaitu harus dilakukan pembaruan terhadap sumber belajar seperti modul sebagai pendukung buku-buku yang sudah ada sehingga akan membuat peserta didik lebih menyukai matematika.

Modul merupakan bahan ajar cetak dalam pembelajaran mandiri dengan topik yang terintegrasi. Modul tersebut berisi informasi yang dibutuhkan siswa untuk mencapai dan menilai pengetahuan dan kemampuan tertentu. Modul merupakan alat atau sarana pembelajaran yang berisi materi, metode, batasan-batasan, dan cara mengevaluasi yang dirancang secara sistematis dan menarik untuk mencapai kompetensi yang diharapkan sesuai dengan tingkat kompleksitasnya (Nelly dan Jailani, 2014).

Adapun penelitian dan pengembangan sebelumnya yang menghasilkan suatu produk yang layak dan efektif digunakan sebagai modul pembelajaran diantaranya; pengembangan modul pembelajaran matematika dengan kerangka elpsa untuk meningkatkan kemampuan berpikir kritis siswa pada materi logika matematika (Kartika, Sanapiah, dan Juliangkary, 2017), pengembangan modul geometri analitik bidang berbantuan wingeom software untuk 
meningkatkan kemampuan representasi matematis (Fonna dan Mursalin, 2018), pengembangan modul berbasis realistik pada materi lingkaran untuk siswa kelas VIII SMP (Hamdunah, Suryani dan Wijaya, 2017), pengembangan modul matematika berbasis active learning untuk memfasilitasi kemampuan berfikir kreatif matematis siswa sekolah menengah pertama (Andriadi, Fitriani, dan Suhandri, 2018), pengembangan modul pembelajaran matematika bermuatan emotional quotient pada pokok bahasan himpunan (Fatikhah dan Izzati, 2015).

Berdasarkan penelitian dan pengembangan yang sudah ada sebelumnya, dalam penelitian ini mengembangkan modul pembelajaran matematika dengan keterbaruan yang dikembangkan berupa modul pembelajaran matematika terintegrasi nilai-nilai keislaman dengan memanfaatkan sekolah yang berlatar belakang keislaman. Pada pengembangan ini modul diberi gambar-gambar kartun islami yang menarik serta informasi-informasi seputar dunia islam dalam kehidupan sehari-hari yang diharapkan bisa memotivasi peserta didik untuk mempelajari matematika.

Tujuan dari penelitian ini adalah (1) untuk mengetahui pengembangan modul matematika terintegrasi dengan nilai-nilai keislaman pada materi statistika berbasis kontekstual, (2) untuk mengetahui kelayakan pengembangan modul matematika terintegrasi dengan nilai-nilai keislaman pada materi statistika berbasis kontekstual, (3) untuk mengetahui respon peserta didik terhadap pengembangan modul matematika terintegrasi dengan nilainilai keislaman pada materi statistika berbasis kontekstual, (4) untuk mengetahui efektifitas pengembangan modul matematika terintegrasi dengan nilai-nilai keislaman pada materi statistika berbasis kontekstual terhadap peserta didik.

\section{METODE PENELITIAN}

Jenis penelitian yang dilakukan adalah penelitian dan pengembangan atau Research and Development $(R \& D)$ (Suci, Asrizal, dan Harman, 2017). Dalam penelitian ini menggunakan model Borg and Gall yang terdiri dari 10 langkah yaitu Potensi dan Masalah, Pengumpulan Data, Desain Produk, Validasi Desain, Revisi Desain, Uji coba Produk, Revisi produk, Uji coba pemakaian, Revisi produk dan Produksi massal.

Terdapat tiga macam instrumen validasi yang akan digunakan yaitu lembar validasi ahli materi, media, dan agama. Validator 1 adalah ahli materi yaitu 2 dosen matematika UIN Raden Intan Lampung dan 1 pendidik MTs Al Huda Bandung Baru; validator 2 adalah ahli media yaitu 2 dosen matematika UIN Raden Intan Lampung dan 1 pendidik MTs Al Huda Bandung Baru; dan validator 3 adalah ahli agama yaitu 1 dosen UIN Raden Intan Lampung.

Setelah itu dilakukan uji coba produk setelah modul telah divalidasi oleh ahli dan uji coba produk ini dilakukan agar dapat diketahui tanggapan dari objek pengembangan modul tersebut. Uji coba produk dilakukan pada responden dalam uji coba kelompok kecil dan uji coba lapangan. Pada uji coba kelompok kecil melibatkan 6 peserta didik dan uji coba lapangan melibatkan 30 peserta didik. Pada uji coba lapangan ini peserta didik diberikan modul yang telah diuji kelayakannya serta diberi angket respon peserta didik. Hal ini dilakukan agar modul yang dikembangkan bisa diketahui kemenarikannya oleh peserta didik pada uji coba kelompok kecil dan 
uji coba lapangan. Dalam uji coba produk ini peserta didik diberi modul kemudian diberikan angket, tujuannya agar dapat mengetahui kemenarikan modul yang dikembangkan menurut pandangan peserta didik.

Setelah itu dilakukan uji coba pemakaian setelah produk diujicobakan dalam kelompok kecil dan lapangan serta telah direvisi dari hasil tanggapan yang diberikan peserta didik. Dalam uji coba pemakaian produk yang berupa modul pembelajaran matematika terintegrasi nilai-nilai keislaman digunakan peserta didik kelas VIII yang berjumlah 30 peserta didik untuk mengetahui tingkat keefektifan dari produk tersebut. Keefektifan dilihat dengan membandingkan pretest dan posttest. Peningkatan yang terjadi sebelum dan sesudah pembelajaran ini diperhitungkan dengan rumus $\mathrm{N}$-gain. Gain adalah selisih antara nilai pretest dan posttest. Gain menunjukkan peningkatan pemahaman atau penguasaan konsep peserta didik setelah pembelajaran yang dilakukan oleh pendidik. Adapun rumus $N$-gain (Oktavia, 2017)

$$
\begin{gathered}
N-\text { gain }=\frac{S_{\text {post }}-S_{\text {pre }}}{S_{\text {maks }}-S_{\text {pre }}} \\
\text { Keterangan }: \\
S_{\text {post }} \quad \text { : skor tes akhir } \\
S_{\text {maks }} \quad \text { : skor maksimum } \\
S_{\text {pre }} \quad \text { : skor tes awal }
\end{gathered}
$$

\section{HASIL PENELITIAN DAN PEMBAHASAN}

Berikut ini hasil pengembangan modul matematika terintegrasi dengan nilai-nilai keislaman pada materi statistika berbasis kontekstual:

\section{Potensi dan Masalah}

Berdasarkan dari angket kuisioner peserta didik diperoleh bahwa bahan ajar yang digunakan disekolah masih bersifat umum seperti buku cetak dan LKPD sehingga peserta didik merasa kurang tertarik dan kurang bersemangat sehingga kurang berminat untuk mempelajari matematika. Sedangkan berdasarkan wawancara dengan pendidik didapat hasil informasi bahwa bahan ajar yang terdapat disekolah masih bersifat umum seperti buku cetak dan LKPD belum ada bahan ajar pendukung lainnya.

2. Pengumpulan Data

Dalam hal ini yang dilakukan peneliti mengumpulkan informasi berupa sumber yang dapat menunjang penyusunan modul pembelajaran matematika, adapun refrensi yaitu: Buku matematika untuk SMP/MTs kelas VIII semester 2 karya Abdul Rahman As'ari, Muhammad Tohir, Erik Valentino, buku matematika untuk SMP/MTs kelas VIII Semester 2 karya M.Cholik Adinawan, buku berlogika dengan matematika untuk kelas VIII SMP dan MTs semester 2 karya Umi Salamah, buku penilaian autentik matematika untuk SMP/MTs kelas VIII semester 2 karya Wono Setya Budhi, dan buku matematika untuk SMP/MTs kelas VIII implementasi kurikulum 2013 semester 2 karya Tim Masmedia Buana.

3. Desain Produk

Penyusunan modul matematika dicocokkan dengan kompetensi dasar yang ada pada kurikulum 2013. Modul pembelajaran matematika ini menggunakan kertas jenis ISO B5, 
skala spasi $1,5 \mathrm{~cm}$, jenis huruf yang digunakan adalah comic sans $m s$, times new roman, serta ayat AlQur'an yang dimasukkan melalui program Add-Ins yang terdapat di laptop. Perlengkapan modul pembelajaran matematika pada materi statistika terintegrasi nilainilai keislaman meliputi beberapa hal seperti pada Gambar 1 dan Gambar 2 berikut.

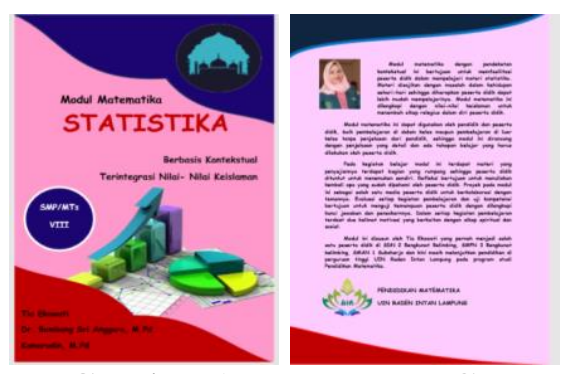

Gambar 1. Rancangan Cover Depan dan Belakang
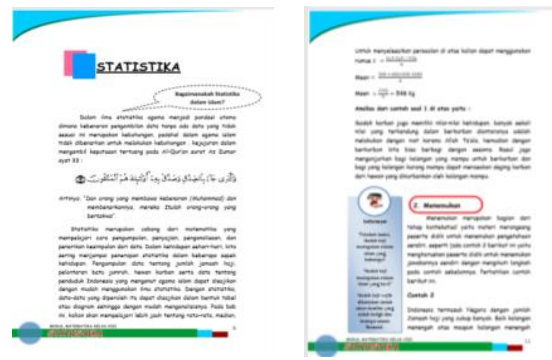

Gambar 2. Rancangan Materi Pembelajaran

4. Validasi Desain

a. Hasil Validasi Ahli Materi

Validasi ahli materi bertujuan untuk mengetahui aspek kualitas isi, aspek kontekstual, dan aspek bahasa dari produk yang dikembangkan. Validator ahli materi melibatkan 3 orang validator, yaitu 2 dosen pendidikan matematika UIN Raden Intan Lampung dan 1 pendidik mata pelajaran Matematika di MTs Al Huda Bandung Baru. Hasil data validasi materi dapat dilihat pada Tabel 1.

Tabel 1. Hasil Validasi Ahli Materi

\begin{tabular}{ccccc}
\hline \multirow{2}{*}{ Validator } & \multicolumn{3}{c}{ Skor Aspek } & Rata-rata \\
\cline { 2 - 4 } & 1 & 2 & 3 & Skor \\
\hline I & 3,7 & 3,8 & 3,7 & 3,7 \\
II & 3,7 & 3,7 & 3,5 & 3,6 \\
III & 4 & 4 & 4 & 4 \\
\hline \multicolumn{3}{c}{ Skor Akhir } & & 3,7
\end{tabular}

Berdasarkan Tabel 1 dapat disimpulkan validator ahli materi menyatakan bahwa materi yang terdapat di dalam modul Valid dan siap untuk diuji cobakan.

\section{b. Hasil Validasi Ahli Media}

Validasi ahli media bertujuan untuk menguji aspek ukuran lembar kerja modul, desain kulit modul dan desain isi modul. Validator ahli media melibatkan 3 orang validator, yaitu 2 dosen pendidikan matematika UIN Raden Intan Lampung dan 1 pendidik matematika MTs Al Huda Bandung Baru. Hasil validasi oleh ahli media disajikan pada Tabel 2.

Tabel 2. Hasil Validasi Ahli Media

\begin{tabular}{ccccc}
\hline \multirow{2}{*}{ Validator } & \multicolumn{3}{c}{ Skor Aspek } & Rata-rata \\
& 1 & 2 & 3 & Skor \\
\hline I & 3 & 3,3 & 3,1 & 3,1 \\
II & 3 & 3 & 3,4 & 3,1 \\
III & 4 & 3,6 & 3,7 & 3,7 \\
\hline \multicolumn{5}{c}{ Skor akhir } \\
\end{tabular}

Berdasarkan Tabel 2 dapat disimpulkan validator ahli media menyatakan bahwa modul Valid dan siap untuk diuji cobakan. 
DOI: https://doi.org/10.24127/ajpm.v8i1.1826

c. Hasil Validasi Ahli Agama

Validasi ahli agama bertujuan untuk menguji aspek kualitas isi, bahasa dan penekanan-penekanan materi. Validator ahli agama melibatkan 1 orang validator, yaitu dosen UIN Raden Intan Lampung. Hasil data validasi materi tahap dapat dilihat pada Tabel 3.

Tabel 3. Hasil Validasi Ahli Agama

\begin{tabular}{ccccc}
\hline \multirow{2}{*}{ Validator } & \multicolumn{3}{c}{ Skor Aspek } & Rata-rata \\
& 1 & 2 & 3 & Skor \\
\hline I & 3,6 & 3,7 & 3,8 & 3,7 \\
& Skor akhir & & 3,7
\end{tabular}

Berdasarkan Tabel 3 dapat disimpulkan validator ahli agama menyatakan bahwa materi yang terdapat di dalam modul Valid dan siap untuk diuji cobakan.

5. Revisi Desain

Setelah dilakukan validasi desain oleh para ahli materi, ahli media dan ahli agama selanjutnya revisi produk sesuai saran dan masukan yang telah diberikan oleh para ahli.

6. Uji Coba Produk

Uji coba produk dilakukan untuk mengetahui respon peserta didik terhadap kemenarikan produk tersebut.

a. Uji coba kelompok kecil

Uji coba kelompok kecil dilakukan pada peserta didik kelas VIII MTs Al Huda Bandung Baru sebanyak 6 orang. Hasil angket respon peserta didik menunjukkan bahwa modul matematika terintegrasi nilai-nilai keislaman "sangat menarik" dengan skor 3,28 .

b. Uji coba Lapangan

$$
\text { Uji coba lapangan }
$$
dilakukan pada peserta didik kelas VIII Al Huda Bandung Baru 30 orang. Hasil angket respon peserta didik menunjukkan bahwa modul matematika terintegrasi nilainilai keislaman "sangat menarik" dengan skor 3,49.

7. Revisi Produk

Setelah dilakukannya uji coba produk, produk dikatakan menarik maka akan dilanjutkan pada tahap uji coba pemakaian.

8. Uji Coba Pemakaian

Setelah dilakukan uji coba kelompok kecil dan uji coba lapangan, pada tahap berikutnya adalah uji efektivitas yaitu dengan mencari selisih skor posttest dan pretest untuk mengetahui hasil kegiatan pembelajaran yang terjadi sebelum dan sesudah menggunakan modul pembelajaran. Soal pretest diberikan sebelum peserta didik menggunakan modul matematika sedangkan soal postest diberikan setelah peserta didik menggunakan modul matematika.

Tabel 4. Hasil Pretest dan Posttest

\begin{tabular}{cccc}
\hline $\begin{array}{c}\text { Skor } \\
\text { ideal }\end{array}$ & $\begin{array}{c}\text { Skor } \\
\text { min }\end{array}$ & $\begin{array}{c}\text { Skor } \\
\text { maks }\end{array}$ & $\begin{array}{c}\text { Rata-rata N- } \\
\text { gain }\end{array}$ \\
\hline 100 & 0,14 & 1 & 0,71 \\
\hline
\end{tabular}

Berdasarkan Tabel 4, hasil postest dan pretest, dapat diketahui nilai tertinggi, nilai terendah, ratarata dan selisih postest dan pretest (gain score).

9. Revisi Produk

Dari hasil uji coba pemakaian yang menggunakan uji coba efektivitas yang telah dilakukan, hasil dari peserta didik diperoleh nilai rata-rata 0,71 . Nilai efektifitas dari nilai rata-rata tersebut masuk dalam kategori tinggi atau dapat dikatakan bahwa modul ini efektif untuk digunakan dan telah selesai 
dikembangkan sehingga menghasilkan produk akhir.

10. Produksi Massal

Produk di sebar di sekolah, program studi pendidikan matematika dan perpustakaan tarbiyah dan keguruan.

Produk yang dikembangkan ini memiliki beberapa kelebihan sebagai berikut:

a. Sebagai panduan belajar untuk peserta didik secara mandiri.

b. modul matematika ini memuat materi statistika.

c. modul matematika ini memuat integrasi nilai-nilai keislaman sehingga dapat menambah nilai relegius dalam diri peserta didik.

Produk yang dikembangkan ini memiliki beberapa kekurangan yaitu materi pada modul ini masih terbatas pada materi statistika saja.

Berdasarkan hasil penelitian dan pengembangan yang diperoleh dapat disimpulkan bahwa modul pembelajaran yang dikembangkan berupa modul pembelajaran matematika pada materi statistika terintegrasi nilainilai keislaman. Langkah awal yang harus dilakukan dalam pengembangan modul adalah mengumpulkan data seperti silabus, RPP, referensi buku yang akan digunakan serta sumbersumber lainnya. Setelah data terkumpul maka langkah selanjutnya mendesain modul menggunakan data yang sudah dikumpulkan, kemudian modul yang telah didesain selanjutnya divalidasi oleh ahli materi, media dan agama. Modul yang telah selesai divalidasi diperbaiki sesuai masukan dari para validator. Modul yang telah selesai direvisi selanjutnya diujicobakan ke sekolah melalui tahap uji coba kelompok kecil dan uji coba lapangan. Setelah tahap uji coba selesai kemudian modul diuji coba pemakaian dengan uji efektivitas menggunakan uji $\mathrm{N}$-gain.

Setelah semua tahap selesai maka bahan ajar berupa modul pembelajaran matematika terintegrasi nilai-nilai keislaman ini layak untuk digunakan dalam kegiatan pembelajaran matematika. Oleh sebab itu diharapkan dengan adanya modul pembelajaran ini dapat membantu peserta didik dalam memanfaatkan lingkungan sekitar yang berlatar belakang islam untuk lebih mengembangkan ilmu yang dimiliki pada kehidupan nyata. Seperti penelitian yang telah dilakukan oleh Rizki dan Linuhung (2016), Mayani dan Rizki (2016), Purwanto dan Rizki (2015) yang telah mengembangkan bahan ajar matematika dengan variasi yang berbeda-beda untuk perkembangan matematika. Oleh karena itu, pengembangan dan inovasi dalam matematika sangat diperlukan untuk mempermudah peserta didik dalam memahami matematika.

\section{KESIMPULAN DAN SARAN}

Berdasarkan penelitian dan pembahasan yang telah dipaparkan, pengembangan modul matematika telah divalidasi oleh ahli materi, ahli media dan ahli agama dengan memperoleh kriteria valid atau layak digunakan dan hasil respon peserta didik memperoleh kategori sangat menarik. Selain itu, pada uji efektivitas menggunakan uji Ngain pretest dan postest memperoleh peningkatan dengan kategori tinggi. Sehingga, dapat disimpulkan bahwa pengembangan berupa modul matematika terintegrasi nilai-nilai keislaman yaitu layak, menarik dan efektif untuk digunakan peserta didik.

Saran-saran yang disampaikan berdasarkan hasil penelitian yang telah dilakukan pada modul matematika terintegrasi dengan nilai-nilai 
keislaman, yaitu modul matematika terintegrasi nilai-nilai keislaman perlu dikembangkan lagi dengan materi yang cakupan lebih luas serta perlu disempurnakan lagi supaya peserta didik termotivasi untuk belajar matematika.

\section{DAFTAR PUSTAKA}

Afifah, D. S., (2012). Interaksi Belajar Matematika Siswa Dalam Pembelajaran Kooperatif Tipe STAD. Jurnal Pegagogia, 1(2), 145-151.

Andriadi, Depi. F., \& Suhandri. (2018). Pengembangan Modul Matematika Berbasis Active Learning untuk Memfasilitasi Kemampuan Berpikir Kreatif Matematis Siswa Sekolah Menengah Pertama. Juring (Journal for Research in Mathematics Learning), 1(1), 55-64.

Effendi, K.N.S., \& Ehda. F. (2017). Kemampuan Berfikir Kreatif Siswa SMP Kelas VII Dalam Penyelesaian Masalah Statistika. Jurnal Analisa, 3(2), 130-137.

Fatikhah, I., \& Nurma, I. (2015). Pengembangan Modul Pembelajaran Matematika Bermuatan Emoticon Quotient Pada Pokok Bahasan Himpunan. EduMa, 4(2), 2086-3981.

Fonna, M., \& Mursalin. (2018). Pengembangan Modul Geometri Analitik Bidang Berbantuan Wingeom Software untuk Meningkatkan Kemampuan Representasi Matematis. UNION: Jurnal Pendidikan Matematika, 6(3), 391-402.

Hamdunah, M. S., \& Fransisca, I. W. (2017). Pengembangan Modul Berbasis Realistik Pada Materi Lingkaran Untuk Siswa Kelas
VIII SMP. Jurnal Pelangi, 9(2), 135-143.

Hardiyantari, O. (2017). Pengembangan Multimedia Pembelajaran Interaktif Menggunakan Teknik Dinamis Pada Mata Pelajaran Produktif Teknik Komputer dan Jaringan Untuk Siswa SMK Kelas X. Jurnal Inovasi Teknologi Pendidikan, 4(1), 7783.

Kartika, Y., Sanapiah \& Eliska, J. (2017). Pengembangan Modul Pembelajaran Matematika Dengan Kerangka ELPSA Untuk Meningkatkan Kemampuan Berpikir Kritis Siswa Pada Materi Logika Matematika. Jurnal Media Pendidikan Matematika, 5(1), 2338-3836.

Lestari, W. \& Handayani, S. (2018). Pengembangan Modul Matematika Berbasis Matematika Realistik Untuk Kelas VII SMP Semester I. Jurnal Analisa, 4(1), 51-60.

Masykur, R., Novrizal, \& Muhammad, S. (2017). Pengembangan Media Pembelajaran Matematika Dengan Macromedia Flash. AlJabar: Jurnal Pendidikan Matematika, 8(2), 177-185.

Mayani, S. dan Rizki, S. (2016). Pengembangan Bahan Ajar Berbasis Pendidikan Matematika Realistik (PMR) Pada Materi Program Linear. AKSIOMA Jurnal Pendidikan Matematika, 5(1), 25-39.

Mulia, D, Netriwati, \& Fraulein, I. S. (2018). Modul Pembelajaran Matematika Bernuansa Islami Dengan Pendekatan Inkuiri. Desimal: Jurnal Matematika, 1(1), 7-13. 
Nasaruddin., (2014). Pembelajaran Matematika Berbasis Islam. Jurnal Al-Khwarizmi, 2(2), 5968.

Nasution, A. (2016). Pengembangan Modul Matematika Berbasis Masalah Untuk Meningkatkan Kemampuan Pemecahan Masalah Matematika Peserta Didik. Jurnal Pendidikan Dan Kependidikan, 1(1), 47-63.

Purwanto, Y. dan Rizki, S. (2015). Pengembangan Bahan Ajar Berbasis Kontekstual Pada Materi Himpunan Berbantu Video Pembelajaran. AKSIOMA Jurnal Pendidikan Matematika, 4(1), 67-77.

Rhosyida, N., \& Jailani. (2014). Pengembangan Modul Matematika SMK Bidang Seni, Kerajinan, Dan Pariwisata Berbasis Open-Ended Problem Sebagai Implementasi KTSP. Jurnal Riset Pendidikan Matematika, 1(1), 38.

Rizki, S. dan Linuhung, N. (2016). Pengembangan Bahan Ajar Program Linear Berbasis Kontekstual dan ICT. AKSIOMA Jurnal Pendidikan Matematika, 5(2), 137-144.

Suci, A., \& Harman. (2017). Pengembangan Bahan Ajar IPA Terpadu Berorientasi Pembelajaran Kontekstual Tema pemanfaatan Tekanan Dalam Kehidupan Untuk Meningkatkan Literasi Peserta didik Kelas VIII SMP. Pillar Of Physics Education, 10, 153-160.

Sugiyono. (2015). Metode Penelitian Pendidikan. Bandung: Alfabeta.

Supriadi, N. (2015). Mengembangkan Kemampuan Koneksi Matematis Melalui Buku Ajar Elektronik Interaktif (BAEI) Yang Terintegrasi Nilai-Nilai
Keislaman. Al-Jabar: Jurnal Pendidikan Matematika, 6(1), 63-73. 